\title{
Seed germination in the Great Basin halophyte Salsola iberica
}

\author{
M. Ajmal Khan, Bilquees Gul, and Darrell J. Weber
}

\begin{abstract}
Salsola iberica Sennen \& Pau, a halophytic forb in the family Chenopodiaceae, is widely distributed in inland salt deserts of Utah and widespread in North America. Experiments were conducted to determine the effects of $\mathrm{NaCl}$ and temperature on seed germination and their recovery of germination from saline conditions after being transferred to distilled water. Seeds of S. iberica were germinated at various temperatures and at various salinities in a $12 \mathrm{~h}$ light : $12 \mathrm{~h}$ dark photoperiod to determine their germinability under these conditions. Increases in $\mathrm{NaCl}$ concentration progressively inhibited seed germination. Few seeds germinated at $1000 \mathrm{mM} \mathrm{NaCl}$. Cooler temperatures significantly inhibited germination, while high night $\left(25^{\circ} \mathrm{C}\right)$ and high day $\left(35^{\circ} \mathrm{C}\right)$ temperature regimes showed higher germination. Rate of germination decreased with an increase in salinity. Germination rate was higher at $25-35^{\circ} \mathrm{C}$ and lower at 5$15^{\circ} \mathrm{C}$ temperatures. Seeds were transferred from salt solutions to distilled water after 20 days, and those from low salinities recovered quickly at cooler temperature regimes. Recovery germination percentages substantially decreased with an increase in salinity and temperature.
\end{abstract}

Key words: halophyte, recovery of seed germination, Salsola iberica, salt desert, thermoperiod, Utah.

Résumé : Le Salsola iberica Sennen \& Pau, une herbe halophyte non-graminéenne de la famille des Chénopodiacées, largement distribuée dans le désert salé continental de l'Utah, est fréquente en Amérique du Nord. Les auteurs ont conduit des essais pour déterminer les effets du $\mathrm{NaCl}$ et de la température sur la germination des graines et leur rétablissement suite à un transfert à l'eau distillée à partir de conditions salines. Les auteurs ont fait germer des graines du S. iberica à diverses températures et salinités, sous une photopériode de $12 \mathrm{~h}$ lumière : $12 \mathrm{~h}$ obscurité, afin de déterminer leur pouvoir germinatif sous ces conditions. Des augmentations de concentration en $\mathrm{NaCl}$ inhibent progressivement la germination des graines. Peu de graines germent en présence de $\mathrm{NaCl} 1000 \mathrm{mM}$. Les températures les plus basses inhibent significativement la germination, alors que des régimes de températures élevées la nuit $\left(25^{\circ} \mathrm{C}\right)$ et élevées le jour $\left(35^{\circ} \mathrm{C}\right)$ conduisent aux germinations les plus importantes. Le taux de germination diminue avec une augmentation de la salinité. Le taux de germination est plus élevé à des températures de $25-35^{\circ} \mathrm{C}$ et plus faible à $5-15^{\circ} \mathrm{C}$. Les graines ont été transférées des solutions salines à l'eau distillée après 20 jours; celles provenant des faibles salinités se sont rétablies plus rapidement à des régimes de basses températures. Les pourcentages de rétablissement de germination diminuent substantiellement avec une augmentation de la salinité et de la température.

Mots clés : halophyte, rétablissement de la germination des graines, Salsola iberica, désert salé, thermopériode.

[Traduit par la Rédaction]

\section{Introduction}

Salsola iberica Sennen \& Pau (Russian thistle or tumbleweed) is one of the most widely occurring alien annual herb species in the saline-disturbed habitats of the western United States (Welsh et al. 1987). This weed was first introduced into the United States in 1873 in flax seeds brought from Russia (Robbins et al. 1952). Russian thistle has now spread to millions of hectares in all western states to the Pacific coast. It is a primary colonizer and a single plant can pro-

Received 11 October 2001. Published on the NRC Research Press Web site at http://canjbot.nrc.ca on 14 June 2002.

M.A. Khan, ${ }^{1}$ B. Gul, ${ }^{1}$ and D.J. Weber. ${ }^{2}$ Department of Botany and Range Science, Brigham Young University, Provo, UT 84602-5181, U.S.A.

${ }^{1}$ Present address: Department of Botany, University of Karachi, Karachi-75270, Pakistan.

${ }^{2}$ Corresponding author (e-mail: Darrell_weber@byu.edu). duce 100000 to 200000 seeds (Robbins et al. 1952). The mature plant may break off at the ground line and be blown by wind, which scatters the seeds as it tumbles along. In the northern Great Basin, Russian thistle germinates in spring and matures as a summer annual. The germination of halophyte seeds in temperate salt playas and salt marshes usually occurs in the spring when the temperatures are lower and soil salinity is reduced by precipitation (Khan and Ungar 1984; Badger and Ungar 1989; Ungar 1995).

The effect of salinity on seed germination of annual halophyte species indicates a great deal of variation in response to hypersaline conditions (Khan and Ungar 1997a, 1997b, 1997c). Maximum halophyte seed germination is reported to occur in distilled water or under reduced salinity stress (Khan et al. 2000). Annual halophytes vary in their upper limit of salt tolerance and increases in salinity usually delay germination (Khan and Ungar 1984, 1997c; Ungar 1996). Species reported to have very high salt tolerance at the germination stage include Salicornia bigelovii $(856 \mathrm{mM} \mathrm{NaCl}$, Rivers and Weber 1971), Salicornia rubra (1000 mM, Khan 
et al. 2000), and Halogeton glomeratus (1000 mM NaCl, Khan et al. 2001c). The rate of germination decreased with an increase in salinity. At higher temperatures, the rate of germination was significantly lower at higher salinities (Khan and Ungar 1997a).

Sensitivity to periodic temperature fluctuation constitutes an important sensory system that enables plants to respond to daily variations in soil surface. Temperature shifts may affect a number of processes determining the germinability of seeds, including membrane permeability, activity of membrane-bound proteins, and cytosol enzymes. Russian thistle matures in time for germination to occur in the fall, but the inherent afterripening requirements severely limit the temperatures at which germination can occur (Young and Evans 1972). At the time of maturity, seeds of Russian thistle are rather specific in their temperature requirement for germination. Therefore, germination is limited to very specific seedbed locations, and germination in the fall is probably restricted to unusually warm and wet autumns in the Great Basin. In the spring, seeds of Russian thistle will germinate under an extremely wide range of temperatures and will consequently have the potential to occupy many different sites (Young and Evans 1972).

Salinity and temperature interact in their control of seed germination, and the greatest inhibition is usually found at the minimum or maximum limits of tolerance for temperature (Khan and Weber 1986). Interactions between salinity, temperature, and seed germination optima occur in halophytes (Hogan 1968; Rivers and Weber 1971; Rozema 1975; Phillipupillai and Ungar 1984; Badger and Ungar 1985; Khan and Ungar 1996, 1998). Phillipupillai and Ungar (1984) determined that Salicornia europaea had optimal germination $(43 \%)$ at $5-15^{\circ} \mathrm{C}$ in $860 \mathrm{mM} \mathrm{NaCl}$ in comparison with $<2 \%$ in other thermoperiods. Khan et al. (2000) reported that germination of Salicorna rubra was significantly higher at a $25-35^{\circ} \mathrm{C}$ thermoperiod at 600 and $800 \mathrm{mM} \mathrm{NaCl}$.

Halophyte seeds have the ability to remain viable for long periods during exposure to hypersaline conditions and then germinate when salinity is reduced (Woodell 1985; Keiffer and Ungar 1995). However, halophytes differ in their capacity to recover from salinity (Woodell 1985; Khan and Ungar $1997 a$ ). This variation in recovery responses could be due to differences in the temperature regimes to which seeds are exposed; Atriplex triangularis, Halogeton maritima, Salicornia rubra, Triglochin maritima, and Zygophyllum simplex provide clear examples of recovery responses affected by temperature regime (Khan and Ungar 1984, 1996, 1999; Khan et al. 2000, 2001c).

Our objective was to study the effect of temperature, salinity, and light on the percent germination, rate of germination, and recovery from salt stress of $S$. iberica seeds.

\section{Materials and methods}

Salsola iberica grows in the highly saline regions of an inland saline flat situated $30 \mathrm{mi}(48.3 \mathrm{~km})$ south of the Great Salt Lake at Faust, Utah. Temperatures range from a minimum of $0^{\circ} \mathrm{C}$ to a maximum of approximately $37^{\circ} \mathrm{C}$. Hansen and Weber (1975) found that temperatures gradually increased from May to July and gradually decreased from
August to September. There are two wet seasons per year, one extending from January to May and the other beginning in July or August. Seeds were collected randomly from the whole population during the fall of 1997 at Faust to get an adequate representation of genetic diversity. Flowering spikes and seeds were removed as the seeds matured. Seeds were spread on tables at room temperature until thoroughly dried and threshed by hand through screens. A small fanning mill was used to separate seeds from chaff. Seeds were stored in sealed plastic jars at $4^{\circ} \mathrm{C}$. Germination studies were started in spring 1997. Seeds were surface sterilized with the fungicide Phygon. Seeds showed $100 \%$ germination in distilled water in a viability test. Germination was carried out in $50 \times 9 \mathrm{~mm}$ (Gelman No. 7232) tight-fitting plastic Petri dishes with $5 \mathrm{~mL}$ of test solution $(0,200,400,600,800$, and $1000 \mathrm{mM} \mathrm{NaCl}$ ). Each dish was placed in a 10-cm-diameter plastic Petri dish to prevent evaporation. Four replicates of 25 seeds were used for each treatment in a completely random design. Treatments were assigned randomly over time. Each experiment was conducted at least twice. Seeds were considered to be germinated with emergence of the radicle.

The effect of temperature on germination was determined for six alternating temperature regimes of 5-15, 10-20, 10 $30,15-25,20-30$, and $25-35^{\circ} \mathrm{C}$. These categories of temperatures reflect spring germination conditions in the Great Basin based on several years of monitoring the microenvironment of seedbeds in the field (Evans et al. 1970; Evans and Young 1972). A 24-h cycle was used where the higher temperature $\left(15,20,30,35^{\circ} \mathrm{C}\right)$ coincided with the 12-h light period (Sylvania cool white fluorescent light, $110 \mu \mathrm{mol}$ photons $\cdot \mathrm{m}^{-2} \cdot \mathrm{s}^{-1}, 400-700 \mathrm{~nm}$ high $\mathrm{red} / \mathrm{far} \mathrm{red}$ ratio) and the lower temperature $\left(5,10,15,25^{\circ} \mathrm{C}\right)$ coincided with the 12-h dark period. Seeds were germinated in distilled water and 200, 400, 600, 800, and $1000 \mathrm{mM} \mathrm{NaCl}$ solutions under the above-mentioned temperature regimes. Percent germination was recorded on alternate days for 20 days. Seeds that did not germinate during the 20 -day $\mathrm{NaCl}$ treatments were transferred to distilled water to study the recovery of germination, which was also recorded at 2-day intervals for 20 days. The recovery percentage was determined by the formula $(a-b) /(c-b) \times 100$, where $a$ is the total number of seeds germinated after being transferred to distilled water, $b$ is the total number of seeds germinated in saline solution, and $c$ is the total number of seeds. The rate of germination was estimated by using a modified Timson index of germination velocity $=\Sigma G / t$, where $G$ is the percentage of seed germination at 2-day intervals and $t$ is the total germination period (Khan and Ungar 1984). The maximum value possible using this index with our data was 50 (i.e., 1000/20). High values reflected rapid germination.

Germination data (20 days and rate of germination) and recovery germination data (20 days and rate of recovery of germination) were transformed (arcsine) before statistical analysis in order to ensure homogeneity of variance. Data were analyzed using SPSS V.7.0 (SPSS Inc. 1999). Effects of salinity and temperature on germination were examined using two-way analysis of variance (ANOVA). A two-way ANOVA was used to demonstrate the significance of main factors (salinity and thermoperiod) and their interaction in affecting the rate and percentage of final germination. A 
Fig. 1. Percent germination (mean $\pm \mathrm{SE}$ ) of Salsola iberica in 0, 200, 400, 600, 800, and $1000 \mathrm{mM} \mathrm{NaCl}$ at temperatures of 5-15, $10-20,15-25,20-30$, and $25-35^{\circ} \mathrm{C}$.
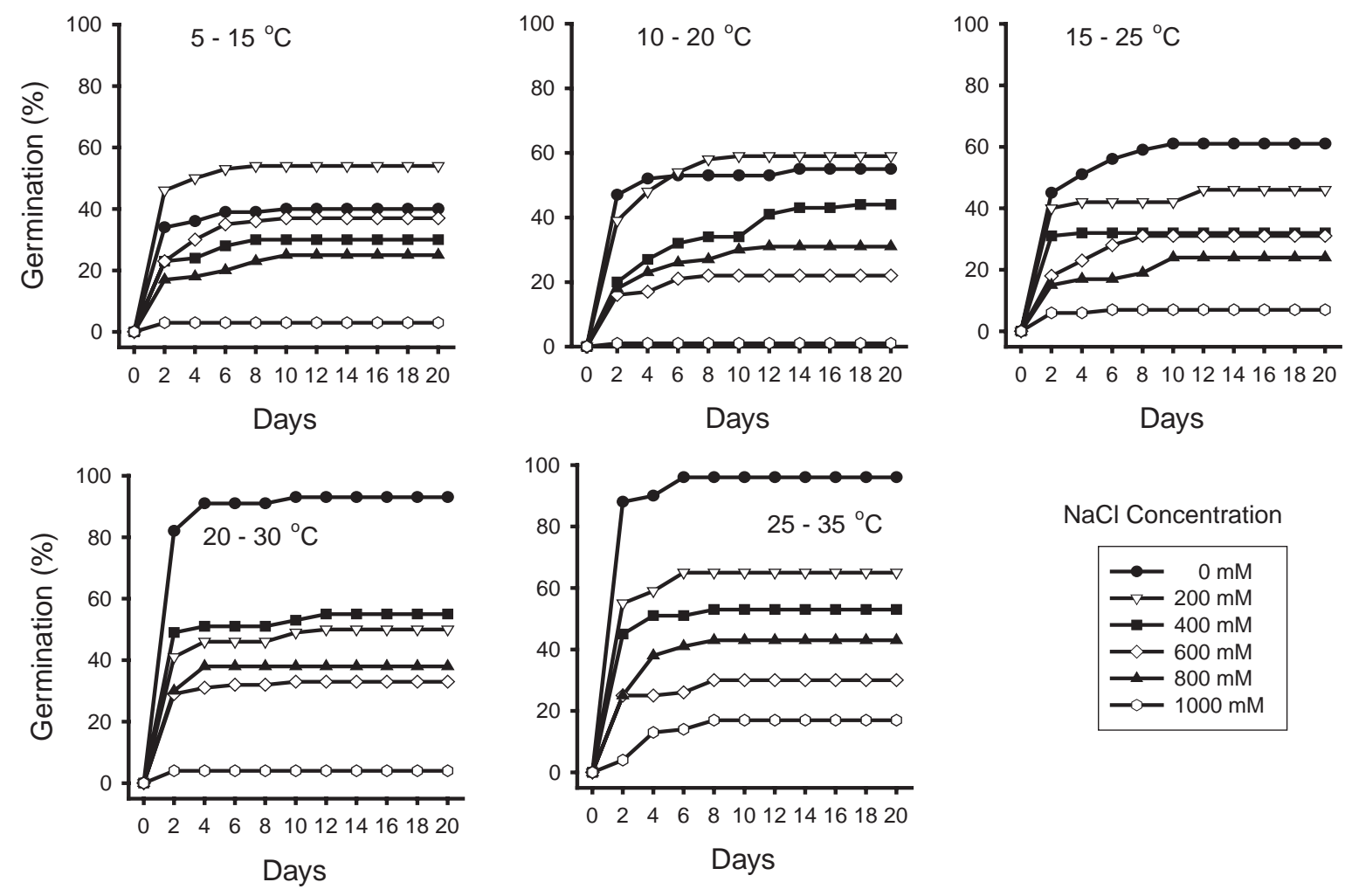

$\mathrm{NaCl}$ Concentration

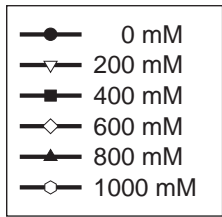

Bonferroni test was used to determine whether differences among means were significant between treatments within each salinity concentration and temperature regime $(P<$ 0.05). A linear regression analysis was used to determine the relationship between salt concentration and germination at different salinities.

\section{Results}

Germination of S. iberica significantly increased at higher temperatures, decreased in higher salinities, and varied with the interaction of the two factors (Table 1). Seed germination was higher in distilled water at all temperature regimes except $5-15$ and $10-20^{\circ} \mathrm{C}$. Only a few seeds germinated at $1000 \mathrm{mM} \mathrm{NaCl}$ (Fig. 1). Germination was strongly affected by temperature. Germination at $5-15^{\circ} \mathrm{C}$ in the nonsaline control was only $50 \%$. Seeds showed higher germination in all treatments at the highest temperature regime $\left(25-35^{\circ} \mathrm{C}\right)$ with $100 \%$ germination in the nonsaline control (Figs. 1 and 2 ). The interaction between salinity and temperature on germination was significant (Table 1). A linear regression explains a high proportion of the germination response with $R^{2}$ values ranging from 0.54 to 0.73 in various temperature treatments (Fig. 2).

The rate of germination calculated by using a modified Timson's index showed that the rate decreased with an increase in salinity at all temperature regimes (Fig. 3). The rate of germination increased with an increase in temperature, and the highest rate of germination occurred in the $25-35^{\circ} \mathrm{C}$ temperature regime (Fig. 3). When seeds were transferred to distilled water after 20 days of salinity treat-
Table 1. Results of two-way ANOVA of characteristics of seed germination of Salsola iberica in relation to salinity, temperature, and salinity $\times$ temperature interactions.

\begin{tabular}{lcll}
\hline Independent variable & Salinity & Thermoperiod & $\begin{array}{l}\text { Salinity } \times \\
\text { thermoperiod }\end{array}$ \\
\hline Percent germination & $141 * * *$ & $21 * * *$ & $4 * * *$ \\
Rate of germination & $130 * * *$ & $32 * * *$ & $5 * * *$ \\
Percent recovery & $4 * *$ & $4 * *$ & $6 * * *$ \\
\hline
\end{tabular}

Note: Numbers represent $F$ values; $* * P<0.01$, *** $P<0.001$.

ment, the recovery germination percentages did not change significantly with increases in pretransfer salinity treatments or with the variation in temperature regimes (Fig. 4).

\section{Discussion}

Salsola iberica was found growing in highly saline habitats at Faust, Utah. Vegetation growing there usually experiences a wide fluctuation in temperature and salinity during the growing season. It ranges from cold subfreezing $\left(-7^{\circ} \mathrm{C}\right)$ spring temperatures to very hot $\left(\sim 37^{\circ} \mathrm{C}\right)$ summer temperatures. Moderate salinity levels occur due to the runoff water from mountains, which accumulates in the playas during early spring (Khan et al. 2001a), but the gradual evaporation of water in late spring and early summer causes a corresponding increase in salinity. Halophytes that germinate under these conditions should have the ability to cope with large variations in temperature and salinity (Khan and Weber 1986; Khan et al. 2000, 2001a, 2001b), and this makes salin- 
Fig. 2. Regression curves of final germination percentages of Salsola iberica at different $\mathrm{NaCl}$ concentrations and thermoperiods.

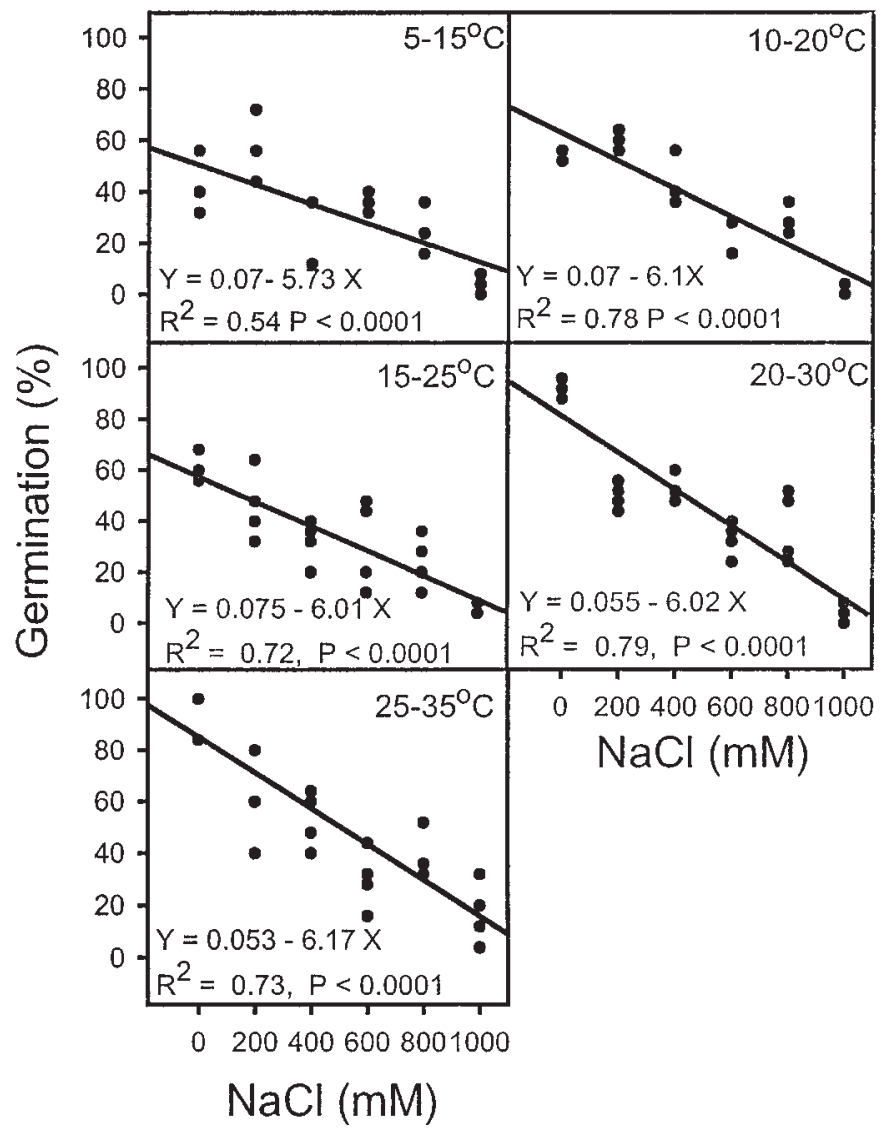

ity and temperature the most important ecological factors determining the germination of Great Basin halophytes.

In general, researchers have concluded that salinity is inhibitory to the germination of halophyte seeds in two ways: (i) causing a complete inhibition of the germination process at salinities beyond the tolerance limits of a species and (ii) delaying the germination of seeds at salinities that cause some stress to seeds but do not prevent germination (Ungar 1995). The germination responses of seeds of annual halophytes to salinity are highly variable and species specific (Ungar 1995). Rivers and Weber (1971) reported that seeds of Salicornia bigelovii could germinate in up to $1369 \mathrm{mM} \mathrm{NaCl}$. Khan and Weber (1986) reported that the germination of the Great Basin halophyte Salicornia pacifica var. uathensis was reduced from $55 \%$ in distilled water to $3 \%$ germination at $856 \mathrm{mM} \mathrm{NaCl}$. No seeds of Allenrolfea occidentalis could germinate beyond $800 \mathrm{mM} \mathrm{NaCl}$ (Gul and Weber 1999). Great Basin halophytes are known to tolerate high salinity at germination, including Salicornia rubra (1000 mM NaCl, Khan et al. 2000), Kochia americana (1712 mM NaCl, Clarke and West 1969), and Sarcobatus vermiculatus, Kochia scoparia, and Suaeda moquinii $(1000 \mathrm{mM} \mathrm{NaCl}$, Khan et al. 2001a, 2001b, 2001c). It is interesting to note that so many highly salt-tolerant species are found in the Great Basin desert compared with few species with similar tolerance reported from elsewhere (Onnis and Miceli 1975; Khan 1991; Khan and Gul 1998).
Fig. 3. Regression curves of rate of germination percentages of Salsola iberica at different $\mathrm{NaCl}$ concentrations and thermoperiods.

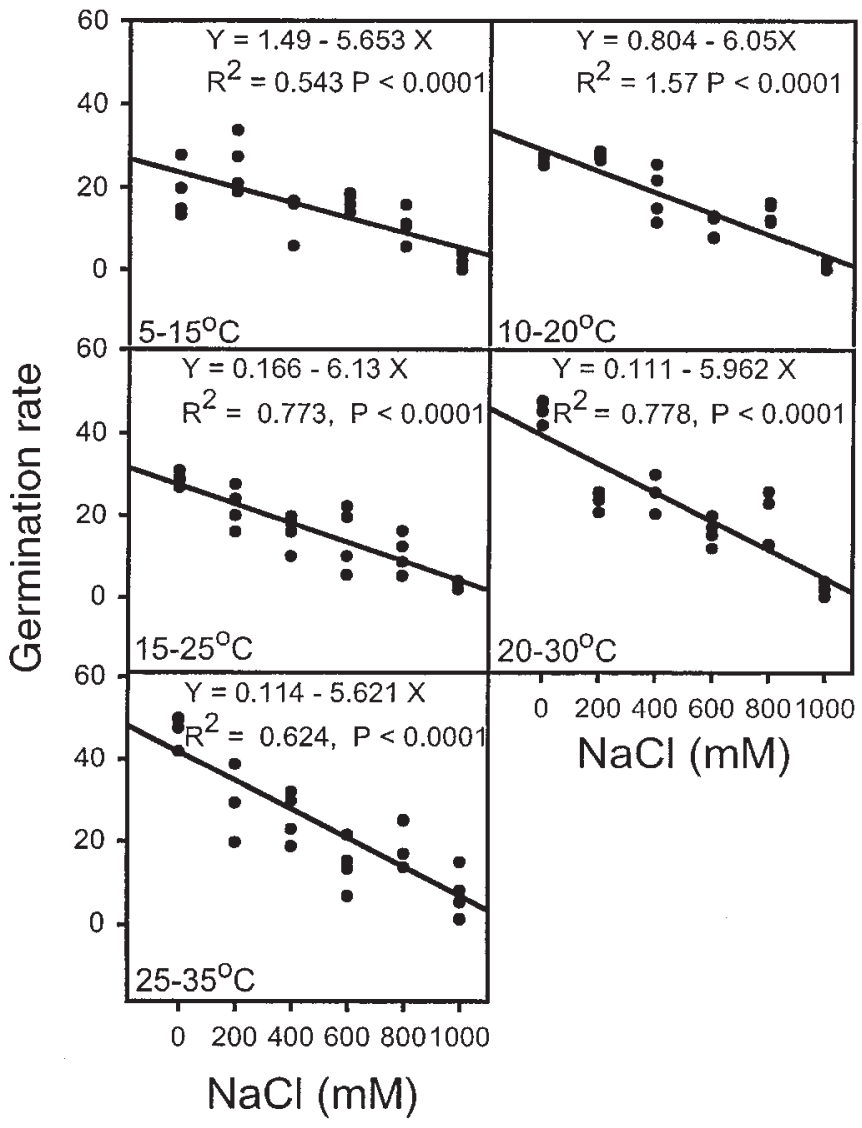

Salinity and temperature are reported to interact in their control of seed germination, and the limits of tolerance to salinity may be greater at one thermoperiod than at another (Khan and Weber 1986; Badger and Ungar 1989; Ismail 1990; Khan and Ungar 1996, 1997a, 1997b, 1997c; Khan et al. 2001a, 2001b, 2001c). An alternating temperature of $35^{\circ} \mathrm{C}$ for $12 \mathrm{~h}$ (light) and $25^{\circ} \mathrm{C}$ for $12 \mathrm{~h}$ (dark) stimulated germination of $S$. iberica in salinities ranging from 0 to $1000 \mathrm{mM} \mathrm{NaCl}$. Our results indicated that warmer alternating temperatures (night:day) were stimulatory for germination. Temperature has an effect on the germination of halophyte seeds in both saline and nonsaline conditions (Khan and Ungar 1997a, 1997b, 1997c). Our study showed that seeds of S. iberica were highly salt tolerant at the germination stage but few seeds germinated at $(-4.38 \mathrm{MPa})$ $1000 \mathrm{mM} \mathrm{NaCl}$. Considering the extreme salt concentrations in the surface of seedbeds in the $S$. iberica communities, salt level would have a negative impact on seed germination. The cooler thermoperiods $\left(5-15,10-20\right.$, and $\left.10-30^{\circ} \mathrm{C}\right)$ inhibited germination considerably at all salinities. At $1000 \mathrm{mM} \mathrm{NaCl}$, maximum germination percentages were obtained at $25-35^{\circ} \mathrm{C}$, which correlates with the temperatures that occur during late spring in Faust. Naidoo and Naicker (1992) found that warmer thermoperiods were more stimulatory to germination in comparison with cooler thermoperiods. Similar results are reported for Allenrolfea occidentalis, Halogeton glomeratus, Kochia scoparia, 
Fig. 4. Percent recovery of germination of Salsola iberica at different $\mathrm{NaCl}$ concentrations and thermoperiods.

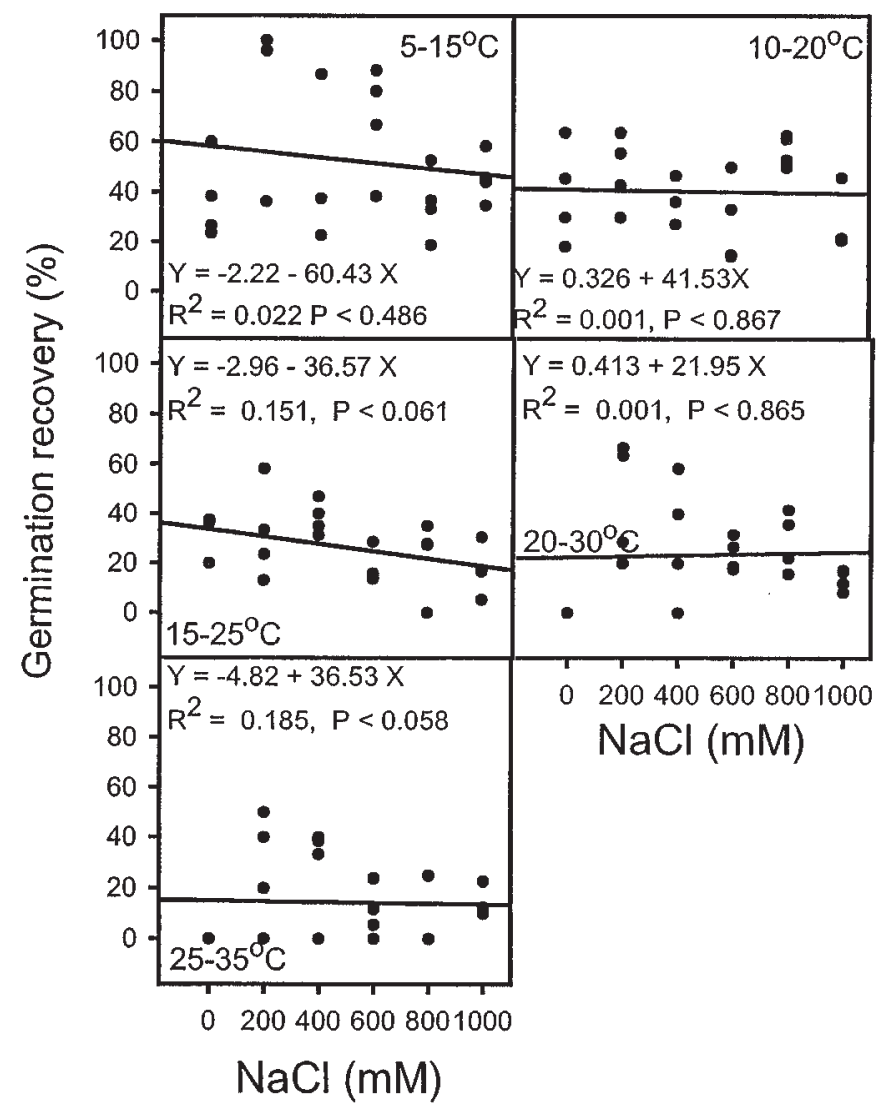

Salicornia rubra, Sarcobatus vermiculatus, and Suaeda moquinii (Gul 1998; Khan et al. 2001a, 2001b, 2001c).

Seeds of $S$. iberica, when transferred to distilled water after a 20-day treatment at various salinity concentrations, responded differentially in the variable temperature regimes. Seeds exposed to low salinity recovered quickly at the lower temperature $\left(5-15^{\circ} \mathrm{C}\right)$, while delayed seed germination was noticed at higher temperatures. Recovery percentages decreased with an increase in salinity in all temperature regimes. Recovery responses were also dependent on temperature, ranging from $80 \%$ recovery at $5-15^{\circ} \mathrm{C}$ to $20 \%$ at $25-35^{\circ} \mathrm{C}$. Those seeds treated with high salinities (600$1000 \mathrm{mM} \mathrm{NaCl}$ ) showed poor recovery from hypersaline conditions when transferred to distilled water.

Salsola iberica seeds could germinate in up to $1000 \mathrm{mM} \mathrm{NaCl}$. This species showed lowest recovery responses at higher salinity treatments except for the highest temperature where $20 \%$ of the seeds germinated at $1000 \mathrm{mM} \mathrm{NaCl}$. Our investigation demonstrates that seeds of S. iberica are highly salt tolerant, and exposure to high salinity and various temperatures does affect their viability. Temperature and salinity interact significantly in their effect on the germination of S. iberica seeds.

\section{References}

Badger, K.S., and Ungar, I.A. 1989. The effects of salinity and temperature on the germination of the inland halophyte Hordeum jubatum. Can. J. Bot. 67: 1420-1425.
Clarke, L.D., and West, N.E. 1969. Germination of Kochia americana in relation to salinity. Agron. J. 20: 286-287.

Evans, R.A., and Young, J.A. 1972. Microsite requirements for establishment of alien annual species in rangeland communities. Weed Sci. 20: 350-356.

Evans, R.A., Holbo, H.R., Eckert, R.E., Jr., and Young, J.A. 1970. Functional environment of downy brome communities in relation to weed control and revegetation. Weed Sci. 18: 154-162.

Gul, B. 1998. Ecophysiology and population biology of the perennial halophytic shrub Allenrolfea occidentalis (S. Wats.) Kuntze (Chenopodiaceae) growing in a salt playa near Goshen, Northwestern, Utah. Ph.D. dissertation, Brigham Young University, Provo, Utah. p. 160.

Gul, B., and Weber, D.J. 1999. Effect of salinity, light, and thermoperiod on the seed germination of Allenrolfea occidentalis. Can. J. Bot. 77: 1-7.

Hansen, D.J., and Weber, D.J. 1975. Environmental factors in relation to the salt content of Salicornia pacifica var. utahensis. Great Basin Nat. 35: 86-96.

Hogan, W.C. 1968. The effect of salinity on the germination and the growth of two halophytes. M.S. thesis, Ohio University, Athens, Ohio. p. 38.

Ismail, A.M.A. 1990. Germination ecophysiology in populations of Zygophyllum qatarense Hadidi from contrasting habitats: effect of temperature, salinity and growth regulators with special reference to fusicoccin. J. Arid Environ. 18: 185-194.

Keiffer, C.W., and Ungar, I.A. 1995. Germination responses of halophyte seeds exposed to prolonged hypersaline conditions. In Biology of salt tolerant plants. Edited by M.A. Khan and I.A. Ungar. Department of Botany, University of Karachi, Karachi, Pakistan. pp. 43-50.

Khan, M.A. 1991. Studies on germination of Cressa cretica. Pak. J. Weed Sci. Res. 4: 89-98.

Khan, M.A, and Gul, B. 1998. High salt tolerance in germinating dimorphic seeds of Arthrocnemum indicum. Int. J. Plant Sci. 159: 826-832.

Khan, M.A., and Ungar, I.A. 1984. Seed polymorphism and germination responses to salinity stress in Atriplex triangularis Willd. Bot. Gaz. 145: 487-494.

Khan, M.A., and Ungar, I.A. 1996. Influence of salinity and temperature on the germination of Haloxylon recurvum. Ann. Bot. 78: $547-551$.

Khan, M.A., and Ungar, I.A. 1997a. Effect of thermoperiod on recovery of seed germination of halophytes from saline conditions. Am. J. Bot. 84: 279-283.

Khan, M.A., and Ungar, I.A. 1997b. Germination response of the subtropical annual halophyte Zygophyllum simplex. Seed Sci. Technol. 25: 83-91.

Khan, M.A, and Ungar, I.A. 1997c. Effects of light, salinity, and thermoperiod on the seed germination of halophytes. Can. J. Bot. 75: 835-841.

Khan, M.A, and Ungar, I.A. 1998. Germination of salt tolerant shrub Suaeda fruticosa from Pakistan: salinity and temperature responses. Seed Sci. Technol. 26: 657-667.

Khan, M.A, and Ungar, I.A. 1999. Seed germination and recovery of Triglochin maritima from salt stress under different thermoperiods. Great Basin Nat. 59: 144-150.

Khan, M.A, and Weber, D.J. 1986. Factors influencing seed germination in Salicornia pacifica var. utahensis. Am. J. Bot. 73: 1163-1167.

Khan, M.A, Gul, B., and Weber, D.J. 2000. Germination responses to Salicornia rubra to temperature and salinity. J. Arid Environ. 45: 207-214. 
Khan, M.A., Gul, B., and Weber, D.J. 2001a. Germination of dimorphic seeds of Suaeda moquinii under high salinity stress. Aust. J. Bot. 49: 185-192.

Khan, M.A., Gul, B., and Weber, D.J. 2001b. Effect of salinity and temperature on the germination of Kochia scoparia. Wetlands Ecol. Manage. 9: 483-489.

Khan, M.A., Gul, B., and Weber, D.J. 2001c. Seed germination characteristics of Halogeton glomeratus. Can. J. Bot. 79: 11891194.

Naidoo, G., and Naicker, K. 1992. Seed germination in the coastal halophytes Triglochin bulbosa and Triglochin striata. Aquat. Bot. 42: 217-229.

Onnis, A., and Miceli, P. 1975. Puccinellia festucaeformis (Host) Parl.: Dormienza e influenza della salinia sulla germinazione. G. Bot. Ital. 109: 27-37.

Philipupallai, J., and Ungar, I.A. 1984. The effect of seed dimorphism on the germination and survival of Salicornia europaea L. populations. Am. J. Bot. 71: 542-549.

Rivers, W.G., and Weber, D.J. 1971. The influence of salinity and temperature on seed germination in Salicornia bigelovii. Physiol. Plant. 24: 73-75.
Robbins, W.W., Crafts, A.S, and Raynor, R.N. 1952. Weed control. McGraw-Hill Book Company, Inc., New York.

Rozema, J. 1975. The influence of salinity, inundation and temperature on the germination of some halophytes and nonhalophytes. Oecol. Plant. 10: 341-353.

SPSS Inc. 1999. SPSS: SPSS base 9.0 application guide. SPSS Inc., Chicago, Ill.

Ungar, I.A. 1995. Seed germination and seed bank ecology in halophytes. In Seed development and seed germination. Edited by J. Kigel and G. Galili. Marcel Dekker, New York. pp. 599-628.

Ungar, I.A. 1996. Effect of salinity on seed germination, growth and ion accumulation of Atriplex patula (Chenopodiaceae). Am. J. Bot. 83: 604-607.

Welsh, S.L., Atwood, N.D., Goodrich, S., and Higgins, L.C. 1987. A Utah flora. Great Basin Nat. Mem. 9: 1-894.

Woodell, S.R.J. 1985. Salinity and seed germination patterns in coastal plants. Vegetatio, 61: 223-229.

Young, J.A., and Evans, R.A. 1972. Germination and establishment of Salsola in relation to seedbed environment. I. Temperature, afterripening, and moisture relations of Salsola seeds as determined by laboratory studies. Agron. J. 64: 214-218. 
Copyright $\odot 2003$ EBSCO Publishing 